\title{
SURVEY ON THE CLINICAL TRIAL RESULTS ACHIEVED IN BRAZIL COMPARING PRAZIQUANTEL AND OXAMNIQUINE IN THE TREATMENT OF MANSONI SCHISTOSOMIASIS
}

\author{
Getûlio Leonel de REZENDE (1)
}

\begin{abstract}
S U M M A R Y
A random, double-blind, parallel group clinical trial program was carried out to compare praziquantel, a recently developed anti-helmintic drug, and oxamniquine, an already established agent for treating mansoni schistosomiasis. Both drugs were administered orally as a single dose, on the average, praziquantel $55 \mathrm{mg} / \mathrm{kg}$ and oxamniquine $16 \mathrm{mg} / \mathrm{kg}$ BWT. The diagnosis and the parasitological follow-up lasting for a minimum of six months, were based on stool examinations according to Kato/Katz technique. A patient was considered cured if all results were negative and if he had performed at least three post-treatment controls, each one comprising three stool examinations. The finding of a single $\mathbf{S}$. mansoni egg in any stool examination indicated a therapeutical failure. A total of 267. cases were treated with praziquantel and 272 with oxamniquine. The two groups :were homogeneous in regard to patients, age, clinical form of the disease, risk of reinfection and worm burden, relevant factors in the therapeutical response. The incidence and severity of untoward effects were similar in both groups but abdominal distress and diarrhoea were more frequently reported under praziquantel and dizzines under oxamniquine $(\mathrm{p}<0.05)$. In the former group a marked urticariform reaction was observed whereas in the latter one patient presented convulsion. The laboratory work-up failed to disclose any significant alteration although the AST, ALT and $\gamma$-GT mean values revealed a tendence to increase on the 7th day after oxamniquine intake. The overall parasitological cure rates were $75.5 \%$ (139/ 184) with praziquantel and $69.8 \%(134 / 192)$ with oxamniquine $(p>0.05)$. Amongst the noncured aptients a reduction of $88.6 \%$ and $74.6 \%$ in the mean number of eggs/g of feces was seen following the treatment with praziquantel and oxamniquine, respectively $(p<0.05$ ). In conclusion, in spite of their different chemical, pharmacological and toxicological profiles as well as mechanisms-of-action, inclusively praziquantel already had proved to be $100 \%$ active against $\mathbf{S}$. mansoni strains resistant to oxamniquine, both drugs showed comparable tolerance and therapeutical efficacy.
\end{abstract}

\section{NTRODUGTION}

Variagated factors seem to play a relevant role in the evaluation of therapeutical response to antischistosome drugs: patients' age; worm burden; clinical form of the disease; risk of reinfection as well as duration, frequency and nature of parasitological control.

(1) Head, Drug Research and Development, E. Merck - Latin America Regional Office. Caixa PostaI 55 077, Rio de Janeiro 22700 - RJ., Brazil

Paper presented at the XI International Congress for Tropical Medicine and Malaria, Calgary, Canada, September $16-22, \quad 1984$ 
REZENDE, G. L. de - Survey on the clinical trial results achieved in Brazil comparing praziquantel and oxamniquine in the treatment of mansoni schistosomiasis. Rev. Inst. Med, trop. Sāo Paulo 27:328-336, 1985.

Therefore, by virtue of the variable sources of patients, the diversity of methodological approaches and the unequal criteria for assessment of therapeutical efficacy, it becomes un. feasible to confront results from distinct in vestigators. Consequently, in order to compare different drugs it is mandatory to develop clinical trials following a randomized, doubleblind, parallel group design. Furthermore, the patients should be stratified in conformity with the relevant factors aiming at achieving homogeneous groups and an uniform criteria for assessing parasitological cure ought to be followed. With the scope of comparing praziquantel - a novel broad-spectrum anti-helmintic agent which is active against all schistosome species pathogenic to man $18,36,37$ - and oxamniquine - an already well established drug for treating mansoni schistosomiasis ${ }^{34}$ - a program comprising five clinical trials was under. taken in Brazil 4,14,24,25,33.

\section{MATERIALS AND METHODS}

A total of 539 out-patients free from pre vious antischistosome treatment participated in the program. Seventy percent were males. The age varied from 8 to 65 years, 'with a mean of 20.6. One fourth consisted in children below 15 years old and solely $9 \%$ were older than 30 . The body 'weight ranged from 17 to $94 \mathrm{~kg}$, in the average 52.4. The great majority, $93 \%$, was constituted of chronic cases and $68 \%$ presented the intestinal form. The mean number of eggs per gram of feces - EPG - was 346 and the limits 24 and 3492. Approximately half of the cases eliminated from 100 to 500 eggs and just $21 \%$ more than 500 . Most of the patients, $78 \%$ were living away from endemic areas. Due to the stratification in accordance with the age, the clinical form of schistosomiasis, the living area and the worm burden as well as to the random allocation of patients, the two groups - 267 cases treated with praziquantel and 272 with oxamniquine - turned out to be homogeneous concerning all relevant factors $\left(\mathrm{X}^{2}-\right.$ $\mathrm{p}>$ 0.5). Table $\mathrm{I}$.

Both drugs 'were administered per os as a single dose, on the average, praziquantel 55 $\mathrm{mg} / \mathrm{kg} \mathrm{BWT}$ (from 42 to 66 ) and oxamniquine $16 \mathrm{mg} / \mathrm{kg} \mathrm{BWT}$ (from 13 to 21 ). The acute cases were treated three months after having been infected. To allow a double-blind administra. tion the two drugs were provided in capsules having an identical appearence but containing different dosages (at a ratio of 3.4) so that the posology was always the same for both drugs regardless the dose variation in relation to each patient's weight. The capsules were dis. pensed within individually coded bottles.

The diagnosis was based on stool exami. nation by the Kato/Katz method 21, one week prior to treatment. The parasitological followup period extended for a minimum of six months and comprised at least three controls - each one involved three consecutive daily stool examinations according to the same quantitative method. The arithmetic mean calculated from the three countings represented the result of each respective control. A patient was considered cured if all results were negative, the finding of a single $\mathbf{S}$. mansoni egg in any stool examination indicated a therapeutical failure.

On the day of treatment the patients were submitted to physical examination and symp. tomatic evaluation. Following the drug intalke they remained under clinical observation during 24 hours to disclose any occurrence of adverse drug reaction. The following laboratory tests were performed prior to and one day after treatment in 53 patients from the pra ziquantel group and in 55 from the oxamniquine group: serum determination of aspartate aminotransferase (AST/SGOT); alamine aminotransferase (ALT/SGPT); gamaglutamyl transpeptidase $(\gamma-G T)$; alkaline phosphatase; total bilirubin; creatinine; fast glucose; blood counting of leucocytes and eosinophils; hemoglobin, hematocrit and urinalysis. The determination of the hepatic enzymes, AST, AIT and $\gamma-G T$ was repeated one week afterwards.

\section{RESULTS}

The overall incidence (72\%) and severity (mostly, 85\%, slight to moderate) of untoward effects were similar in both groups. Usually, they appeared within the first four to six hours and did not last Ionger than one day. However, gastrointestinal complaints tended to be more frequently refered under praziquantel intake and neurological symptoms under oxamniqui ne. Table II. 
REZENDE, G. L. de - Survey on the clinical trial results achieved in Brazil comparing praziquantel and onamniquine in the treatment of mansoni schistosomiasis. Rev. Inst. Med. trop. Sāo Paulo 27:328-336, 1985.

T A B L E I

Characteristic of the patients

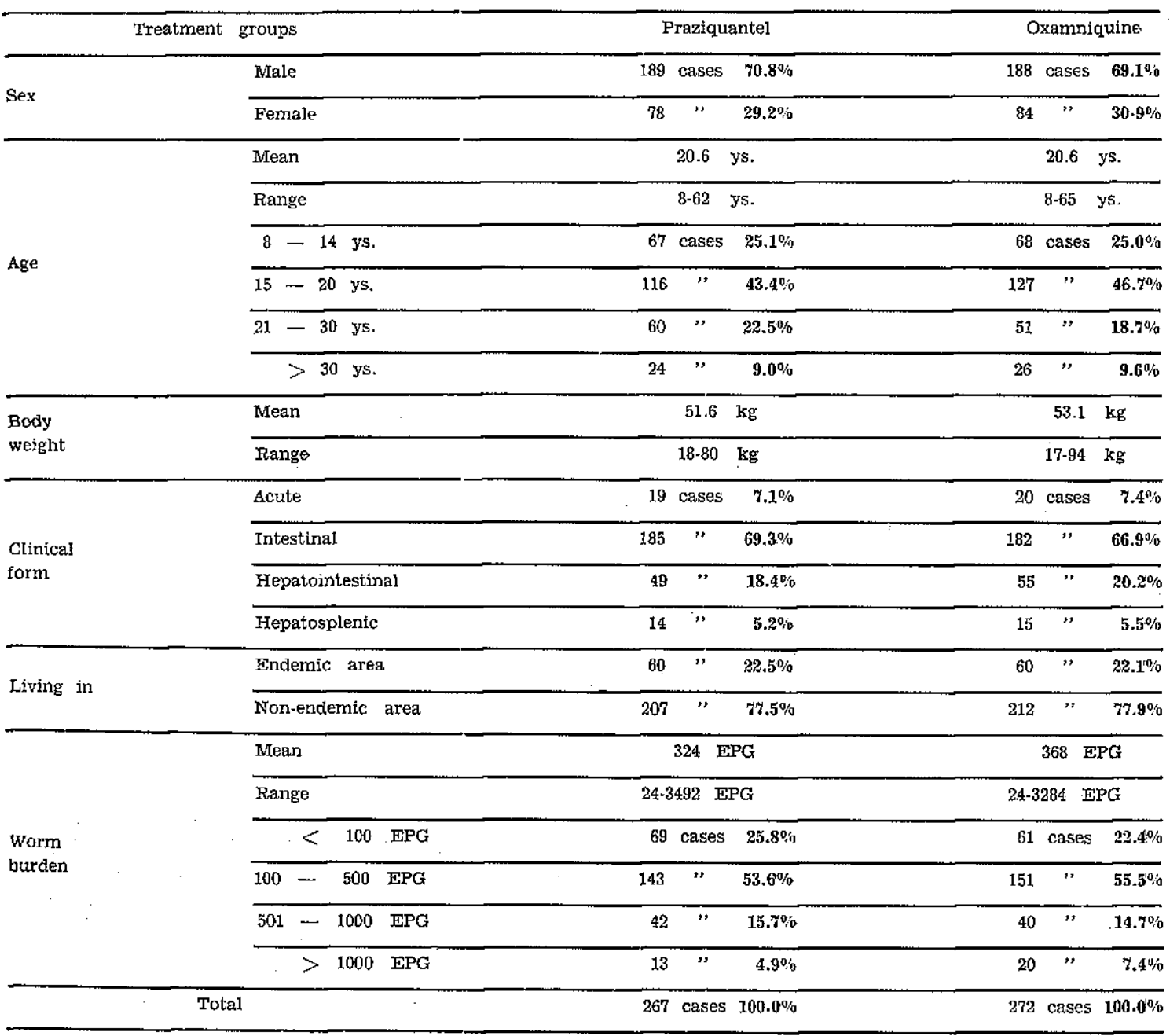

Actually, abdominal distress and diarrhoea were reported at a significantly higher percentage $\left(X^{2}: p<0.05\right)$ with praziquantel whereas dizziness with oxamniquine. Moreover, 'with the former drug a marked urticariform reaction was observed in two cases and fever in five. With the latter drug three patients complained of blurring of vision and one suffered an episode of seizure (a generalized tonic-clonic convulsion which lasted for a few minutes only and subsided spontaneously. The patient denied any past-history of epileptic fits).

The laboratory work-up, besides eosinophilia which is commonly found in schistoso. motic patients, failed to demonstrate any re levant abnormality in both treatment groups in spite that the mean AST, $\gamma$-GT and ALT values revealed a tendence to augment on the 7th day after oxamniquine intake. Table III. On the other hand, the percentage of the aforementioned liver enzyme results that have changed from normal to abnormal post-treatment with either drug was not just low but similar to the percentage of changes the other way round (Mc Nemar test : $p>0.05$ ), Table IV.

Amongst the 267 patients treated with praziquantel 22 cases did not veturn for the parasitological follow-up and 45 had positive stool examination. Whilst 139 cases were consi 
REZENDE, G. L. de - Survey on the clinical trial results achieved in Brazil comparing praziquantel and oxamniquine in the treatment of mansoni schistosomiasis. Rev. Inst. Med. trop. São Paulo 27:328-336, 1985.

T A B L E II

Occurrence of side-effects

\begin{tabular}{|c|c|c|c|c|}
\hline Treatment groups & \multicolumn{2}{|c|}{$\begin{array}{c}\text { Praziquantel } \\
267 \text { cases }\end{array}$} & \multicolumn{2}{|c|}{$\begin{array}{l}\text { Oxamniquine } \\
269 \text { cases }\end{array}$} \\
\hline Total incidence & \multicolumn{2}{|c|}{$73.8 \%$} & \multicolumn{2}{|c|}{$69.5 \%$} \\
\hline \multirow{3}{*}{ Intensity } & \multicolumn{2}{|c|}{$57.5 \%$} & \multicolumn{2}{|c|}{$\mathbf{5 4 . 6} \%$} \\
\hline & \multicolumn{2}{|c|}{$28.6 \%$} & \multicolumn{2}{|c|}{$29.8 \%$} \\
\hline & \multicolumn{2}{|c|}{$13.9 \%$} & \multicolumn{2}{|c|}{$15.6 \%$} \\
\hline Complaints & No. & $\%$ & No. & $\%$ \\
\hline Dizziness ${ }^{*}$ & 90 & 33.7 & 116 & 43.1 \\
\hline Abdominal distress ${ }^{*}$ & 122 & $45.7 y$ & 46 & 17.1 \\
\hline Drowsiness & 39 & 14.6 & 38 & 14.1 \\
\hline Headache & 26 & 9.7 & 36 & 13.4 \\
\hline Nausea & 32 & 12.0 & 28 & 10.4 \\
\hline Diarrhoea ${ }^{*}$ & 32 & 12.0 & 14 & 5.2 \\
\hline Asthenia & 20 & 7.5 & 15 & 5.6 \\
\hline Vomiting & 15 & 5.6 & 19 & 7.1 \\
\hline Anorexia & 7 & 2.6 & 4 & 1.5 \\
\hline Malaise & 4 & 1.5 & 3 & 1.1 \\
\hline Pruritus & 4 & 1.5 & 2 & 0.7 \\
\hline Fever & 4 & 1.5 & - & 一 \\
\hline Myalgia & - & 一 & 4 & 1.5 \\
\hline Blurring of vision & 一 & $\dot{-}$ & 3 & 1.1 \\
\hline Ưrticariform & 2 & 0.7 & - & 一 \\
\hline Convulsion & - & 一 & 1 & 0.4 \\
\hline
\end{tabular}

dered cured, 61 with negative results were not evaluated since they did not complete the required three controls. In the oxamniquine group, with 272 patients, 58 were therapeutical failures and the drop-out rate was $5 \% \quad(13$ cases). Sixty seven did not complete the minimum of three negative controls and were not evaluated but 134 cases were considered cured. In both groups the cured patients have performed, in the average, 11 stool examinations per case. Table V.

The overall parasitological cure rates were $75.5 \%(139 / 184)$ with praziquantel and $69.8 \%$ (134/192) with oxamniquine. This difference $(5.7 \%)$ was not statistically significant ( $Z$ test for difference of proportion $: p>0.05$ ). Table VI.
Analysing the cure rates in relation to relevant factors one observes that there was a clear trend towards achieving poorer results in patients under 15 years old. Such trend was also found, but mainly with oxamniquine, in patients living at endemic areas and in those presenting higher worm burden. Confronting the two drugs regarding each factor, the results were quite comparable although in children, in heavier infected cases and in those originated from endemic areas, the cure rates revealed a tendence to be lower in the oxamniquine group. Nevertheless, none of these differences had statistical significance ( $Z$ test for difference of proportions : $p>0.05$ ).

Considering the non-cured patients, a reduction of $88.6 \%$ (from 386 to 44 ) and of $74.6 \%$ (from 452 to 115) in the mean number of eggs eliminated per gram of feces was seen following the treatment with praziquantel and oxamniquine, respectively. This difference $(14 \%)$ was statistically significant (Mann-Whithney test : $\mathrm{p}<0.05)$. Table VII.

\section{DISCUSSION}

Taking into account the prospective concurrent comparison between praziquantel and oxamniquine, the homogenity of the treated groups and the uniformity of criteria for assessment of efficacy and tolerance, these results can be regarded as reliable evidence on the therapeutical properties of both schistosomicide agents, at these dose levels, against mansoni schistosomiasis in Brazil. It is worthy to be noticed that their tolerance and efficacy were quite similar despite that praziquantel - an isoquinoline-pyrazino compound - and oxamniquine - a mirasan derivative - have different chemical structures, Fig. 1, as well as distinct pharmacological and toxicological profiles $1,16,17$.

Concerning tolerance one may suppose that many complaints particularly those involving the abdomen, are triggered by the interaction between drug and parasites and not by the drug itself. Inclusively, most of these symptoms already are present prior to treatment ${ }^{38}$. Fur. thermore, some side-effects, like skin rashes. might result from allergic reactions to heteroantigens released from the dead parasites. On the other hand, neuropsychiatric disturbances, 
REZENDE, G. L. de - Survey on the clinical trial results achieved in Brazil comparing praziquantel and oxamniquine

in the treatment of mansoni schistosomiasis. Rev. Inst. Med. trop. São Paulo 27:328-336, 1985.

T A B L E III

Results of the laboratorial investigation (mean values)

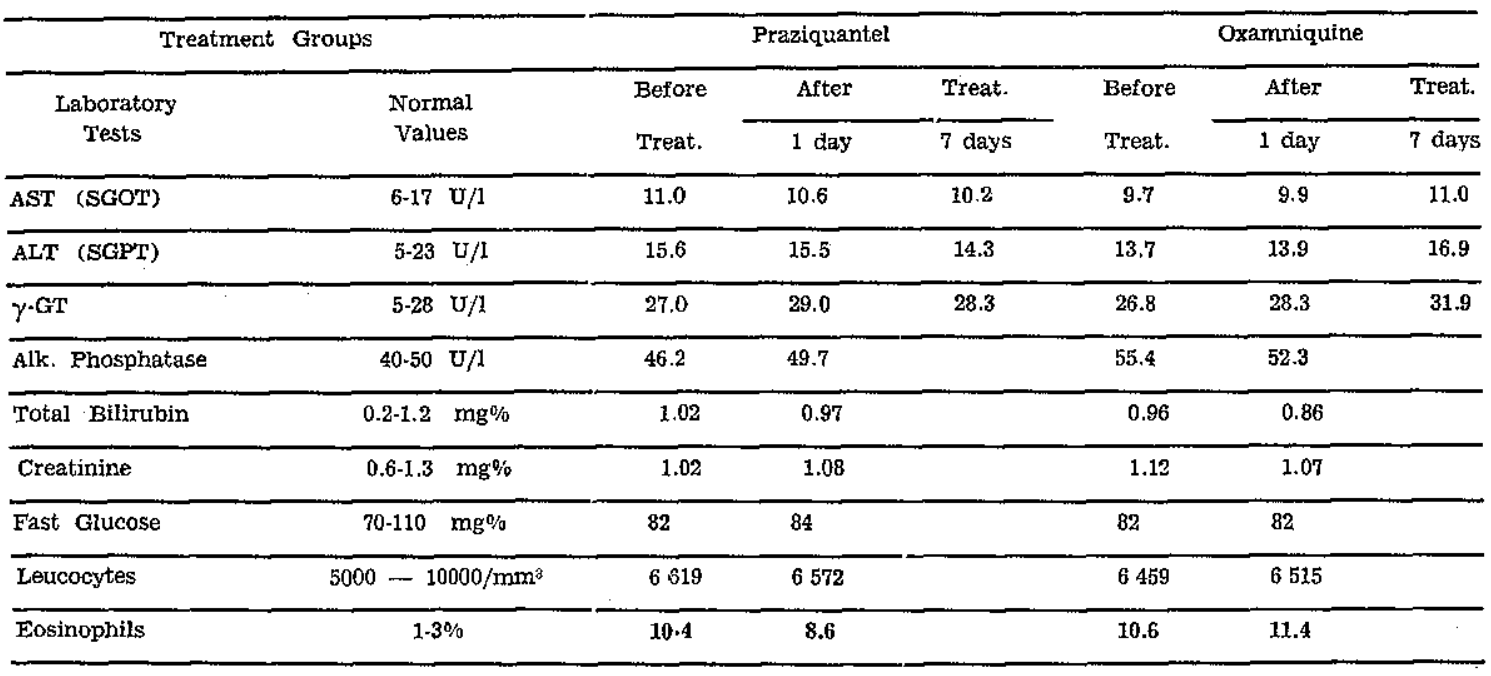

T A B L $\mathrm{E}$ IV

Liver enzyme values that have changed from normal to ahnormal (N $\rightarrow$ A) or from abnormal to normal (A $\rightarrow$ N) after treatment

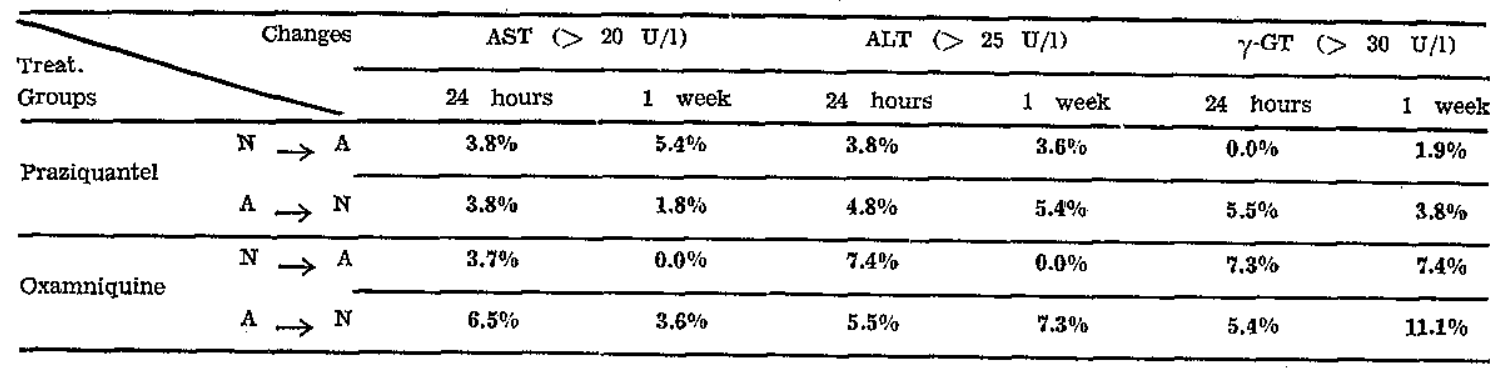

T A B I E V

Parasitological follow-up (three stool examinations according to Kato/Katz method in each control)

\begin{tabular}{|c|c|c|c|c|c|c|c|c|c|}
\hline \multirow{3}{*}{\multicolumn{2}{|c|}{$\begin{array}{l}\text { Parasitological } \\
\text { follow-up }\end{array}$}} & \multicolumn{4}{|c|}{ Praziquantel } & \multicolumn{4}{|c|}{ Oxamniquine } \\
\hline & & \multicolumn{2}{|c|}{ Patients } & \multicolumn{2}{|c|}{ Stool exam. } & \multicolumn{2}{|c|}{ Patients } & \multicolumn{2}{|c|}{ Stool exam. } \\
\hline & & No. & $\%$ & Total & Mean & No. & $\%$ & Total & Mean \\
\hline 6 negative controls & & 11 & 4.1 & 198 & & 15 & 5.5 & 270 & \\
\hline $5 \quad " \quad "$ & & 8 & 3.0 & 120 & & 2 & 0.7 & 30 & \\
\hline $4 \quad " 11$ & & 41 & 15.4 & 492 & & 38 & 14.0 & 456 & \\
\hline $3 \quad ", \quad "$ & & 79 & 29.6 & 711 & & 79 & 29.1 & 711 & \\
\hline Total of cured cases & & 139 & 52.1 & 1521 & 10.9 & 134 & 49.3 & 1467 & 10.9 \\
\hline 2 negative controls & & 43 & $16 \cdot 1$ & & & 52 & 18.1 & & \\
\hline 1 negative control & & 18 & 6.7 & & & 15 & 5.5 & & \\
\hline 0 control (drop-outs) & & 22 & 8.2 & & & 13 & $4 \cdot 8$ & & \\
\hline Positive controls & & 45 & 16.9 & & & 58 & 21.3 & & \\
\hline Total of treated cases & & 267 & 100.0 & & & 272 & 100.0 & & \\
\hline
\end{tabular}


REZENDE, G. L. de - Survey on the clinical trial results achieved in Brazil comparing praziquantel and oxamniquine in the treatment of mansoni schistosomiasis. Rev. Inst. Med. trop. São Paulo 27:328-336, 1985.

T A B L E VI

Terapeutical efficacy

\begin{tabular}{|c|c|c|c|c|c|c|c|}
\hline \multirow{2}{*}{\multicolumn{2}{|c|}{ Number of cases }} & \multicolumn{3}{|c|}{ Praziquantel } & \multicolumn{3}{|c|}{ Oxamniquine } \\
\hline & & \multirow{2}{*}{$\frac{\text { Controlled }}{132}$} & \multicolumn{2}{|c|}{ Cured } & \multirow{2}{*}{$\frac{\text { Controlled }}{129}$} & \multicolumn{2}{|c|}{ Cured * } \\
\hline \multirow{2}{*}{ Sex } & Male & & 102 & $77.3 \%$ & & 91 & $70.5 \%$ \\
\hline & Fernale & 52 & 37 & $71.1 \%$ & 63 & 43 & $68.2 \%$ \\
\hline \multirow{2}{*}{ Age group } & Children $(<15$ ys, old $)$ & 45 & 28 & $62.2 \%$ & 43 & 25 & $54.3 \%$ \\
\hline & Adults & 139 & 111 & $79.9 \%$ & 146 & 109 & $74.7 \%$ \\
\hline \multirow{2}{*}{$\begin{array}{l}\text { Clinical } \\
\text { form }\end{array}$} & Acute & 10 & 9 & $90.0 \%$ & 13 & 12 & $92.3 \%$ \\
\hline & Chronic & 174 & 130 & $74.7 \%$ & 179 & $12 ?$ & $68.2 \%$ \\
\hline \multirow{2}{*}{ fiving in } & Endemic area & 38 & 26 & $68.4 \%$ & 39 & 22 & $56.4^{\circ} ;$ \\
\hline & Non-endemic area & 146 & 113 & $77.4 \%$ & 153 & 112 & $73.2 \%$ \\
\hline \multirow{3}{*}{$\begin{array}{l}\text { Worm } \\
\text { purden }\end{array}$} & $<500 \mathrm{EPG}$ & 143 & 110 & $76.9 \%$ & 149 & 108 & $72.5 \%$ \\
\hline & $>500 \mathrm{EPG}$ & 41 & 29 & $70.7 \%$ & 43 & 26 & $60.5 \%$ \\
\hline & Total & 184 & 139 & $75.5 \%$ & 192 & 134 & $69.8 \%$ \\
\hline
\end{tabular}

- Negative stool examination (Kato/Katz method)

T A B L E VII

Reduction of the EGG load (mean and standard deviation) due to the treatment

\begin{tabular}{|c|c|c|c|c|}
\hline \multirow{2}{*}{$\begin{array}{l}\text { Treatment } \\
\text { groups }\end{array}$} & \multirow{2}{*}{$\begin{array}{l}\text { Non-cured } \\
\text { patients }\end{array}$} & \multicolumn{2}{|c|}{ Number of eggs/g of feces } & Reduction \\
\hline & & Before treat. & After treat. * * & $\%$ \\
\hline Praziquantel & 45 & $386 \pm 419$ & $44 \pm 32$ & 88.6 \\
\hline Oxamniquine & 58 & $452 \pm 224$ & $115 \pm 216$ & 74.6 \\
\hline
\end{tabular}

* p $>0.05 * 0.05$

A

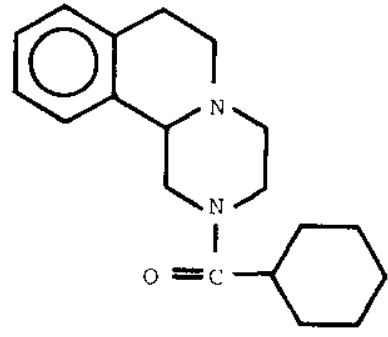

$2-($ CYCLOHEXYI,CARBONIL) - $1,2,3,6,7,11 \mathrm{~b}-$

HEXAHYDRO-4-H-PYRAZINE $(2,1-\mathrm{a})-$

ISOQUINOLIN-4-ONE

Fig. 1 - Chemical structure of praziquantel (A) and oxamniquine (B)
B

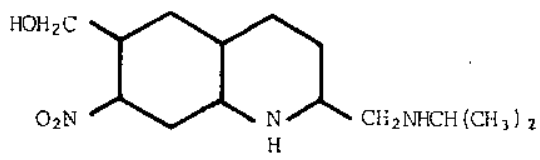

6-AYDROXYMETHYL-2-ISOPROPYLAMINOMETHYL-7-NITRO-1, 2,3,4-

TETRAHYDROQUINOLINE namely convulsion, deserve careful consideration. In the medical literature there are a few reports on the occurrence of seizures and electroencephalographyc alterations associated with the administration of oxamniquine $3,6,8,26$. In previous clinical trials' with praziquantel 
REZENDE, G. L. de - Survey on the clinical trial results achieved in Brazil comparing praziquantel and oxamniquine in the treatment of mansoni schistosomiasis. Rev. Inst. Med. trop. São Paulo 27:328-336, 1985.

the electroencephalogram recording studied in 106 hepatosplenic patients did not reveal any significant changes $7,9,32$.

The laboratory work-up showed no important abnormality with either drug. Moreover, other investigators also detected no relevant alteration of liver function tests - AST, AET, $\gamma$-GT, LAP, ALH, BSP - in 160 hepatosplenic cases treated with praziquantel 7,10,32. Actually, the liver function tests re-evaluated six months after the drug administration were improved 10 .

Concerning efficacy one should not admit, by virtue of their comparable cure rates, that both drugs are equally efficacions and could thus be interchangeable without therapeutical consequences. They act through different mechanisms of action so that the susceptibility of schistosomes to each drug is not the same. Actually, praziquantel has proved experimen. tally to be $100 \%$ effective against $\mathrm{S}$. mansoni strains totally resistant to oxamniquine and refractory patients to repeated treatment courses with oxamniquine have become negative after praziquantel administration $5,13,20,22$.

The overall cure rates particularly in children, $54.3 \%$ to $62.2 \%$, achieved with oxamniquine and praziquantel, respectively, in the treatment of mansoni schistosomiasis cannot be regarded as very satisfactory so that one must look for means to accomplish better results.

In respect to praziquantel one may envisage the use of higher doses since this drug is almost devoided of toxicity. In previous clinical trials there was no consistent direct correlation bet. ween dose increase and frequency or severity of untoward effects $9,15,23,27$. For treating neurocysticercosis it has been employed daily doses of : $75 \mathrm{mg} / \mathrm{kg}$ during seven consecutive days in South Korea ${ }^{30} ; 90 \mathrm{mg} / \mathrm{kg}$ for two days in China ${ }^{39}$ and; $50 \mathrm{mg} / \mathrm{kg}$ during three weeks in Brazil 35. In the treatment of schistosomotic children living in endemic areas in the Brazilian Northeast Region two clinical trials were car. ried out : in one 50 and $70 \mathrm{mg} / \mathrm{kg}$, single doses were compared reaching cure rates of 59 and $74 \%$, respectively ( $\mathrm{X}^{2}: \mathrm{p}<0.05$ ) 15 ; in the other a cure rate of $77 \%$ was obtained with $80 \mathrm{mg} / \mathrm{kg}$ divided into two intakes four hours apart ${ }^{19}$. Another approach would be the administration of praziquantel for two to three consecutive days instead of a single dose intake. Such schedule has been successful in other human trematode infections - clonorchiasis, opisto. chiasis, paragonimiasis - which did not respond satisfactorily to just one day treatment 2,29 . This dose schedule is now being tried in Brazil showing quite promising preliminary findings 11 .

A different possibility refers to the concurrent administration of praziquantel plus oxamniquine. Indeed, a sinergistic effect has been proved experimentally with the combination of these two drugs and a few clinical trials already have been carried out in Africa $12,28,31$.

\section{RESUMO}

Levantamento dos resultados das pesquisas clínicas realizadas no Brasil, comparando o praziquantel com a oxamniquina no tratamento da esquistossomose mansônica.

Um programa de avaliação terapêutica duplo-cega, segundo esquema de grupos paralelos constituídos aleatoriamente, foi realizado para comparar o praziquantel, um anti-helmíntico recentemente desenvolvido, com a oxaminiquina, uma droga já consolidada no tratamento da esquistossomose mansônica. Ambos os medicamentos foram administrados por via oral em dose única, na média, $55 \mathrm{mg} / \mathrm{kg}$ de peso cor. poral para o praziquantel e $16 \mathrm{mg} / \mathrm{kg}$ para a oxamniquina. O diagnóstico, bem como o acompanhamento parasitológico, com duração minima de seis meses, basearam-se em exames de fezes pelo método de Kato/Katz. O paciente cujos resultados foram todos negativos e que completou, pelo menos, três controles pós-tra: tamento, cada um compreendendo três coproscopias, foi considerado curado. O achado de um únicio ovo de $\mathbf{S}$. mansoni em qualquer dos exames de fezes representou uma falha terapêutica.

Um total de 267 casos foi tratado com praziquantel e $272 \mathrm{com}$ oxamniquina. Os dois grupos eram homogêneos quanto à idade dos pacientes, a forma clínica da doença, o risco de reinfecção e a carga parasitária, fatores relevantes na resposta terapêutica. A incidência e a intensidade dos efeitos indesejáveis foram semelhantes em ambos os grupos, embora des. conforto abdominal e diarréia fossem significativamente mais frequientes com praziquantel 
REZENDE, G. L. de - Survey on the clinical trial results achieved in Brazil comparing praziquantel and oxamniquine in the treatment of mansoni schistosomiasis. Rev. Inst. Med. trop. São Paulo 27:328-336, 1985.

e tontura com oxamniquina $(p<0.05$ ). Ademais, no primeiro grupo observou-se uma acentuada reação ulticariforme e no segundo houve uma ocorrência de convulsão. A investigação laboratorial não evidenciou alterações significativas, porém a média dos valores de AST, ALT e $\gamma$-GT mostrou uma tendência a aumentar no sétimo dia após a administração da oxamniquina. A cura parasitológica global com praziquantel atingiu $75,5 \%(139 / 184)$ e com oxamniquina $69,8 \%(134 / 192)$, diferença sem significado estatístico $(\mathrm{p}>0.05)$. Dentre os pacientes não curados, houve, após o tratamento, uma redução no número médio de ovos por grama' de fezes de $88,6 \%$ e $74,6 \%$ com prazi. quantel e com oxamniquina, respectivamente, uma diferença estatisticamente significativa ( $p$ $<0.05$ ).

Em conclusão, apesar de serem substâncias com estruturas químicas diversas, de possuírem propriedades farmacológicas e toxicológicas distintas, bem como mecanismos de ação próprios, inclusive tendo o praziquantel já demonstrado ser $100 \%$ ativo contra linhagens de S. mansoni resistentes à oxamniquina, ambas as drogas evidenciaram tolerabilidade e eficácia terapêutica similares.

\section{ACKNOWLEDGMENT}

The Author wishes to express his gratitude to Dr. Aluizio Rosa Prata, Dr. Luiz Caetano da Silva, Dr. Maria Luiz Moretti Branchini and Dr. Naftale Katz for having placed at this disposal the case report forms of their respective patients from which the data used for the elaboration of this paper were drawn out. It also should be emphasized that the evaluation and interpretation of these data are the sole liability of the Author.

\section{REFERENCES}

1. ANDREWS, P. - A summary of the efficacy of praziquantel against schistosome in animal experiments and notes on its mode of action. Drug Res. 31 (Supl. I): $538-541,1981$.

2. BAYER, A. G. - International Symposium on human trematode infections in Southeast and East Asia, Kyongju, South Korea, October 19-21, 1983.

3. BINA, J. C. \& SPINOLA, A. - Convulsão associada ao uso de oxaminiquina. Relato de um caso. Rev. Soc. Bras. Med. Trop. I0: 221-223, 1976.

4. BRANCHINI, M. L. M.; PEDRO, R. de J.; DIAS, L. C. de S. \& DEBERALDINI, E. R. - Double-blind clinical trial comparing praziquantel with oxamniquine in the treatment of patients with schistosomiasis mansoni Rev. Inst. Med. trop. Săo Paulo 24: 315-321, 1982.

5. CAMARGO, S. de - Tratamento com praziquantel de portadores de esquistossomose, em área endêmica, com persistência de positividade após sucessivas administra. çōes de oxaminiquine. Rev. Inst. Med. trop. São Paulo 24: $180.187,1982$.

6. CARVALHO, S. A. de; MEIRA, J. A. \& AMATO NETO, V. - Ensaio clínico-terapêutico com o oxaminiquine. Estudo sobre sua toxicidade e eficácia.. XV Congresso da Sociedade Brasileira de Medicina Tropical, Campinas, Brazil, February 4-8, 1979.

7. CARVALHO, S. A. de; AMATO NETO, V.; ZEITUNE, J. M. R.; GOLDBAUM, M.; CASTILHO, E. A. de \& GROSSMAN, R. M. - Avaliação terapêutica do praziquantel na infeçăo humaria pelo $\mathrm{S}$. mansoni. Rev. Inst. Med. trop. São PauIo 26: 51-59, 1984.

8. COUTINHO, A. D.; DOMINGUES, A. L. C. \& BONFIM, J. R. A. - Treatment of mansoni schistosomiasis with oxamniquine. Rev. Inst. Med. trop. São Paulo 15: $15-34,1973$

9. COUTINHO, A. D.; DOMINGUES, A. L. C.; NEVES, J. \& ALMEIDA, S. T. - Treatment of hepatesplenic schistosomiasis mansoni with praziquantel. Drug Res. 33: $787-791,1983$.

10. COUTINHO, A. D.; DOMINGUES, A. L. C.; FLOREN. CIO, J. N. \& ALMEIDA, S. T. - Tratamento da esquistossomose mansônica hepatesplênica com praziquantel. Rev. Inst. Med. trop. São Paulo 26: 38-50, 1984.

11. CUNHA, A. S. da - Estudo de diferentes esquemas posológicos do praziquantel, através o método do oograma quantitativo, na esquistossomose mansoni. Personal communication.

12. DIAS, E. P.; KATZ, N. \& ARAUJO, N. - Associação de drogas esquistossomicidas na terapêtica experimental de camundongos, XVI Congresso da Sociedade Brasileira de Medicina Tropical, Natal, Brazil, February $3-8,1980$.

13. DIAS, L. C. de S.; PEDRO, R. de J. \& DEBERALDINI, E. R. - Use of praziquantel in patients with sichostosomiasis mansoni previously treated with oxamniquine and/or hycanthone: resistance of Schistosoma mansoni to schistosomicidal agents. Trans. Roy. Soc. Trop. Med. Hyg. 76: 652-659, 1982.

14. EMANUUEL, A. \& PRATA, A. - Comparaçăo entre praziquantel e oxaminiquine no tratamento da esquistos. somose mansoni. Rev. Soc. Brasil. Med, Trop. 16: 90-93, 1983.

15. EMANUEL, A. \& PRATA, A. - Praziquantel no trata. mento da esquistossomose mansoni em crianças. Rev. Inst. Med. trop. São Paulo 25: 178-181, 1983.

16. FOSTER, R. - The preclinical development of oxamniquine. Rev. Inst. Med. trop. São Paulo 15 (Supl. 1): 1-9, 1973. 
REZENDE, G. L, de - Survey on the clinical trial results achieved in Brazil comparing praziquantel and oxamniquine in the treatment of mansoni schistosomiasis. Rev. Inst. Med. trop. São Paulo 27:328-336, 1985.

17. FROHBERG, H. \& SCHENGKING, M. S. - Toxicological profile of praziquantel, a new drug against cestode and schistosome infections, as compared to some other schistosomicides. Drug Res. 31 (Supl. I): 555-565, 1981.

18. GONNERT, R. \& ANDREWS, P. - Praziquantel, a new broad-spectrum antischistosome agent. Z. Parasitenk. 52: 129-150, 1977.

19. HUGGINS, D.; PERETRA, M. do S. \& FONSECA, C. A. - Tratamento com praziquantel da esquistossomose maansônica em crianças. F. méd (BR) 89: 423-426, 1984.

20. JAIMES, J. B. \& SCHMIDT-DOMMERQUE, F. - Ensayo terapéutico con praziquantel en casos de schistosomiasis mansoni resistentes al oxamniquine. Trib. Med. (Ven.) 54: $6-7,1981$.

21. KATZ. N.; CHAVES, A. \& PELLEGRINO, J. - A simple device for quantitative stool thick-smear technique in schistosomiasis mansoni. Rev. Inst. Med. trop. São Paulo 14: 397-400, 1972.

22. KATZ, N.; DIAS, E. P.; ARAUJO, M. \& SOUZA, C. P. - Estudo de uma cepa humana de Schistosoma mansoni resistente a agentes esquistossomicidas. Rev. Soc. Brasil. Med. Trop. 7: 381-387, 1973.

23. KATZ, N.; ROCHA, R. S. \& CHAVES, A. - Clinical trials with praziquantel in schistosomiasis mansoni. Rev. Inst. Med. trop. São Paulo 23: 72-78, 1981.

24. KATZ, N. \& ROCHA, S. - Double-blind clinical trial comparing praziquantel with oxamniquine in schistosomiasis mansoni. Rev. Inst. Met. trop. Săo Paulo 24: $310-314,1982$

25. KATZ, N.; ROCHA, R. S.; LAMBERTUCCI, J. R.; GRECO, D. B.; PEDROSO, E. R. P.; ROCHA, M. O C. \& FLAN, S. - Clinical trial with oxamniquine and praziquantel in the acute and chronic phases of schistosomiasis mansoni. Rev. Inst. Med. trop. São Paulo 25: 173.177, 1983.

26. KKEYSTONE, J. S. - Seizures and electroencephalograph changes associated with oxamnicuine therapy. Am. J. Trop. Med. Hyg. 2\%: 360-332, 1978.

27. PRATA, A.; CASTRO, C. N.; SILVA, A. E.; PAIVA M.; MACEDO, V. \& JUNQUEIRA JR., L. F. Praziquantel no tratamento da esquistossomose mansoni. Rev. Inst. Med, trop. São Paulo 24: 95-103, 1982.

28. PUGH, R. N. H. \& TEESDALE, C. H. - Synergy of concurrent low dose oxamniquine and praziquantel in schistosomiasis. Br. Med. J. 287: 877.878, 1983.
29. RIM, H-J. \& YOO, K-S. - Chemotherapeutic effect of praziquantel in the treatment of chlonorchiasis sinensis. Korea Univ. Med. J. 16: 459-470, 1979.

30. RIM, H-J.; JOO, K-H. \& HYUN, I. - A therapeutical trial of praziquantel on human cysticercosis (derma) and cerebral) in Korea, V International Congress of Parasitology, Toronto, Canada, August 7-14, 1982.

31. SHAW, J. R. \& BRAMER, K. W. - The treatment of experimental schistosomiasis with a combination of oxamniquine and praziquantel. Trans. Roy. Soc. Trop. Med. Hyg, ri: 39-40, 1983.

32. SILVA, L. C. da; SETTE JR., H.; CHRISTO, C. H.; SAEZ-ALQUEZAR, A.; CARNEIRO, C. R. W.; LACET, C. M.; OHTSUKI, N. \& RAIA, S. - Praziquantel in the treatment of the hepatosplenic form of schistosomiasis mansoni. Drug Res. 31 (Supl. I): 601-603, 1981.

33. SILVA, L. C. da; SETTE JR., H.; CHRISTO, C. H.; SAEZ-ALQUEZAR, A.; PINTO, P. L. S.; ROSA, L. M F. \& ZEITUNE, J. M. R. - Treatment of patients with mansoni schistosomiasis; a double-blind clinical trial comparing praziquantel with oxamniquine, XVIII Congresso Panamericano de Gastroenterologia, Guatema. 1a, November 14-18, 1983.

34. Simpósio sobre oxamniquine - Rev. Inst. Med. trop. São Paulo 22 (Supl. 4), 1980.

35. SPINA-FRANCA, A.; NOBREGA, J. P. S.; LIVRAMENTO, J. A. \& MACHADO, L. R. - Administration of praziquantel in neurocysticercosis. Tropenmed. Parasit. 33: $1-4,1982$

36. THOMAS, H. \& GöNNERT, R. - The efficacy of praziquantel against cestodes in animals. Z. Parasitenk. 52: $117-127,1977$.

37. WEBBE, G. \& JAMES, C. - A comparison of the susceptibility to praziquantel of Schistosoma haematobiun, $S$. japonicum. $S$. mansoni, $S$. intercalatum and S. matteei in hamsters. Z. Parasitenk. 52: 169-177, 1977.

38. WEGNER, D. H. G. - Current state of praziquantel. v International Congress of Parasitology, Toronto, Canada, August 7-14, 1982

39. ZHU, M. F. - Preliminary clinical observations of cysticercosis treated with praziquantel. Nat. Med. $\boldsymbol{J}$. China 65: 545, 1981.

Recebido para publicação em 17/10/1984. 